\title{
OPTIMASI FORMULASI BISKUIT TEPUNG JERAMI NANGKA SEBAGAI SUMBER PANGAN FUNGSIONAL (BETAKAROTEN)
}

\author{
Jaka Rukmana \\ Program Studi Teknologi Pangan, Fakultas Teknik, Universitas Pasundan, Jl. Dr.Setiabudi No 93, Bandung, 40153, \\ Indonesia \\ E-mail : jakarukmana@unpas.ac.id
}

\begin{abstract}
Abstrak
Tujuan umum dari penelitian ini adalah untuk pencapaian ketahanan pangan Indonesia melalui pembangunan industri hilir berbahan baku tepung nangka, tepung biji nangka, dan tepung jerami nangka. Tujuan khususnya adalah untuk melakukan kajian mengenai optimasi formulasi biskuit berbahan dasar tepung jerami nangka dengan menggunakan aplikasi Design Expert metode Mixture D-Optimal.Penelitian ini dilakukan melalui 5 tahapan. tahap pertama adalah analisis bahan baku, tahap kedua adalah penentuan variabel dan penentuan respon, tahap ketiga adalah penentuan formulasi dengan Design Expert metode Mixture D-Optimal, tahap keempat adalah pembuatan dan pengujian respon produk,dan tahap kelima adalah penentuan formula terpilih dan pengujian formula terpilih. Bahan-bahan yang digunakan yaitu : tepung jerami nangka, tepung biji nangka, tepung nangka, air, gula stevia, margarin, garam dapur, telur, dan natrium bikarbonat. Dengan respon yang akan digunakan adalah kadar vitamin A. Berdasarkan hasil penelitian dapat disimpulkan bahwa Design Expert Metode Mixture D-Optimal dapat digunakan untuk mengoptimasi proses pembuatan biskuit tepung jerami nangka dengan nilai desirability 0,899 .
\end{abstract}

Kata kunci: optimalisasi, formulasi, biskuit, tepung jerami nangka, vitamin A

\section{Pendahuluan}

Pola konsumsi masyarakat saat ini sudah mulai beranjak dari pola konsumsi enak atau tidak namun masyarakat sudah mempertimbangkan aspek gizi dari makanan yang dikonsumsinya, termasuk nilai keamanan dan manfat bagi tubuh.

Cookies menurut SNI 01-2973-1992 yaitu biskuit yang dibuat dari adonan lunak berkadar lemak tinggi, renyah dan bila dipatahkan penampang potongannya bertekstur kurang padat. Biasanya terbuat dari tepung terigu dan memiliki bentuk dan rasa yang beraneka ragam (Saputra,2014). Gandum yang merupakan bahan dasar pembuat tepung terigu sampai saat ini kondisinya masih harus diimpor dari Negara lain. Untuk mengurangi konsumsi tepung terigu maka pada penelitian ini akan dilakukan pembuatan produk biskuit berbahan dasar tepung jerami nangka yang merupakan bahan yang kaya akan betakaroten.

Produksi buah nangka di Indonesia menurut Kementerian Pertanian (2015) disajikan pada Gambar 1. Produksi buah nangka mengalami fluktuasi dari tahun 2003 sampai tahun 2013. Produksi buah nangka mencapai 578.327 ton pada tahun 2010. Produksi buah nangka mengalami peningkatan sebesar $13,2 \%$ pada tahun 2011 menjadi 654.808 ton dan pada tahun 2012 mengalami peningkatan kembali menjadi 663.930 ton. Produksi buah nangka pada tahun 2013 menurun sebesar $11,7 \%$ menjadi 586.366 ton.

Optimalisasi formulasi merupakan sebuah metode untuk menentukan formula optimal berdasarkan respon yang diamati. Penentuan optimalisasi formulasi dapat dilakukan dengan berbagai metode diantaranya metode simplex dengan pemograman linier menggunalam software lindo, fasilitas solver pada Microsoft Excel, dan Design Expert metode Mixture D-optimal (Wulandari, 2016).

Metode Design Expert digunakan untuk optimalisasisi proses. Design Expert menyediakan beberapa pilihan desain dengan fungsinya masingmasing, salah satunya adalah Mixture Design yang berfungsi untuk menemukan formulasi optimal (Bas dan Boyaci, 2007 dalam Wulandari, 2016).

\section{Metode Penelitian \\ Penelitian Tahap Pertama}

Analisis yang akan dilakukan adalah analisis kadar betakaroten untuk tepung jerami nangka.

\section{Penelitian Tahap Kedua}

Bahan-bahan yang digunakan sebagai variabel berubah yaitu tepung jerami nangka dengan batas atas hingga batas bawahnya 50-30\%, tepung nangka dengan batas atas hingga batas bawahnya $20-10 \%$, dan tepung biji nangka dengan batas atas hingga batas bawahnya $20-10 \%$. Sedangkan untuk variabel tetapnya adalah air, gula stevia, margarin, garam dapur, telur, dan natrium bikarbonat.

\section{Penelitian Tahap Ketiga}

Penentuan formula menggunakan aplikasi Design Expert versi 10.0 dengan menginput data variabel bebas dan respon yang telah ditentukan sebelumnya (kadar vitamin A) 


\section{Penelitian Tahap Keempat}

Produk biskuit tepung jerami nangka akan dilakukan pengujian vitamin A. Data hasil pengujian Vitamin A akan diinput ke dalam kolom respon pada software design expert versi 10.0 untuk melakukan optimasi formulasi dengan metode Mixture D-Optimal.

\section{Penelitian Tahap Kelima}

Data hasil analisis kemudian dioptimasi dengan program Design Expert Metode D-Optimal untuk mendapatkan suatu formulasi terpilih, formula terpilih kemudian akan dilakukan pengujian kembali sesuai dengan respon yang ditentukan.

\section{Hasil dan Pembahasan}

Penelitian Tahap Pertama

Tabel 1. Hasil Analisis Bahan Baku

\begin{tabular}{|c|c|c|}
\hline Analisis & $\begin{array}{c}\text { Jerami } \\
\text { Nangka }\end{array}$ & $\begin{array}{c}\text { Tepung Jerami } \\
\text { Nangka }\end{array}$ \\
\hline Kadar Vitamin A & $80 \mathrm{IU}$ & $40,20 \mathrm{IU}$ \\
\hline
\end{tabular}

\section{Penelitian Tahap Kedua}

Variabel yang digunakan yaitu tepung jerami nangka, tepung nangka, dan tepung biji nangka. Respon yang digunakan pada produk yaitu respon kimia (analisis kadar vitamin A)

\section{Penelitian Tahap Ketiga}

Berikut ini adalah formulasi biskuit tepung jerami nangka hasil rekomendasi software Design Expert

Tabel 2. Formulasi Biskuit Tepung Jeramni Nangka

\begin{tabular}{|c|c|c|c|}
\hline Formulasi & $\begin{array}{c}\text { Tepung } \\
\text { Jerami } \\
\text { Nangka }(\%)\end{array}$ & $\begin{array}{c}\text { Tepung } \\
\text { Nangka } \\
(\%)\end{array}$ & $\begin{array}{c}\text { Jepung } \\
\text { Biji } \\
\text { Nangka } \\
(\%)\end{array}$ \\
\hline F1 & 45.501 & 19.399 & 17.100 \\
\hline F2 & 46.991 & 19.492 & 15.517 \\
\hline F3 & 44.739 & 17.329 & 19.932 \\
\hline F4 & 47.000 & 16.680 & 18.320 \\
\hline F5 & 44.745 & 18.431 & 18.824 \\
\hline F6 & 46.667 & 15.443 & 19.890 \\
\hline F7 & 48.500 & 17.375 & 16.125 \\
\hline F8 & 44.000 & 18.299 & 19.701 \\
\hline F9 & 47.000 & 17.871 & 17.029 \\
\hline F10 & 47.500 & 16.043 & 18.457 \\
\hline F11 & 46.505 & 17.560 & 17.935 \\
\hline
\end{tabular}

\section{Penelitian Tahap Keempat}

Berdasarkan tabel ANOVA untuk respon kadar vitamin A biskuit tepung jerami nangka, memperlihatkan pada 11 formulasi yang ditawarkan oleh software design expert versi 10.0 menyatakan perlakuan yang diberikan berpengaruh terhadap respon yang diteliti, hal ini ditunjukan dengan nilai probabilitas lebih kecil dari 0,05 yaitu 0,001.

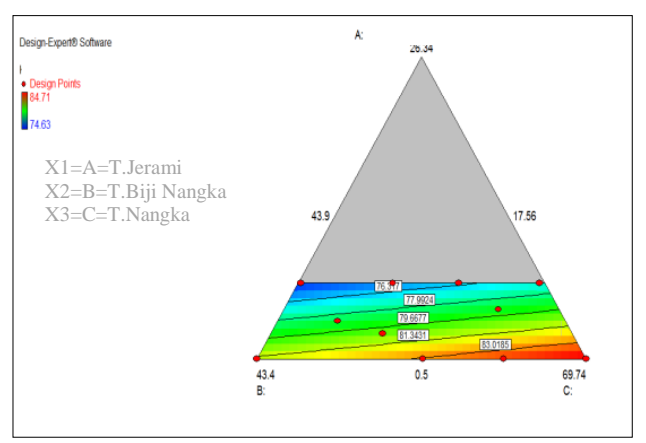

Gambar 1. Grafik Design Expert 11 Formulasi Biskuit Tepung Jerami Nangka Berdasarkan Respon Kadar Vitamin A

Warna merah pada grafik yang terdapat pada Gambar 1, menunjukan nilai kadar vitamin A tertinggi. Posisi warna merah terletak pada sudut variabel c (komponen tepung nangka), hal ini menunjukkan peningkatan kadar Vitamin A dipengaruhi oleh penambahan tepung nangka.

Fokus penelitian yang dilakukan sebenarnya ingin mengoptimalkan penggunakaan tepung jerami nangka pada proses pembuatan biskuit. Namun berdasarkan hasil analisis software design expert versi 10.0 terdapat bias dikarenakan adanya penambahan tepung nangka yang kadar vitamin A nya lebih besar daari jerami nangka. Sebaiknya penelitian lanjutan tepung nangka tidak dijadikan variabel bebas.

\section{Penelitian Tahap Kelima}

Design Expert metode Mixture D-Optimal telah merekomendasikan 1 formulasi optimum dengan nilai desirability sebesar 0,899. Nilai ketepatan formula tersebut dapat dilihat pada nilai desirability tersebut.. Desirability adalah derajat ketepatan hasil formulasi optimal. Semakin mendekati angka satu maka semakin tinggi nilai ketepatan formula.

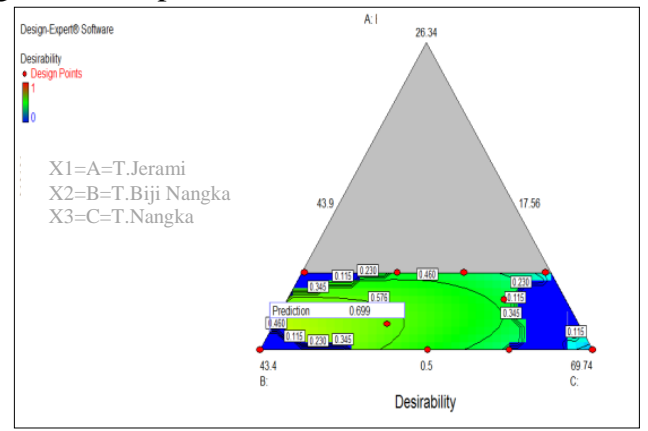

Gambar 2. Grafik Desirability Formulasi Terpilih Biskuit tepung Jerami Nangka 
Dalam upaya memverifikasi data yang direkomendasikan oleh software design expert versi 10.0, maka dilakukan pengujian ulang terhadap produk dengan formula optimum yang direkomendasikan software. Hasil uji dan perbandingan nya dapat dilihat pada Tabel 3.

Tabel 3. Perbandingan dan Standar Deviasi Hasil Analisis Design Expert dengan Hasil Analisis Laboratorium Formulasi Terpilih Biskuit Tepung Jerami nangka

\begin{tabular}{|c|c|c|c|}
\hline Respon & $\begin{array}{c}\text { Design } \\
\text { Expert }\end{array}$ & Laboratorium & $\begin{array}{c}\text { Standar } \\
\text { Deviasi }\end{array}$ \\
\hline $\begin{array}{c}\text { Kadar } \\
\text { Vitamin A }\end{array}$ & $42,005 \mathrm{IU}$ & 42.27IU & 0.18 \\
\hline
\end{tabular}

Berdasarkan hasil penelitian yang telah dilakukan dapat disimpulkan bahwa Program Design Expert versi 10.0 metode Mixture D-Optimal dapat digunakan untuk menentukan formula optimum pembuatan suatu produk.

\section{Ucapan Terimakasih}

Penulis mengucapkan terimakasih yang sebesarbesarnya kepada Fakultas Teknik Universitas Pasundan, yang telah membiayai seluruh biaya penelitian melalui skema Hibah Penelitian Fakultas Teknik Tahun 2018.

\section{DAFTAR PUSTAKA}

AOAC. 2005. Official Methode of Analysis of The Associaton of Official Analytical Chemist. Association of Official Analytical Chemist. Washington D.C.

Kementrian Pertanian. 2015. Statistik Produksi Hortikultura. Direktorat Jendral Hortikultura. Jakarta.

Nugroho, A. 2012. Pemanfaatan Software dalam Penelitian. Universitas Gajah Mada. Yogyakarta.

Saputra, H. P., (2014). Pengaruh Penggunaan Tepung Koro Benguk (Mucuna pruriesns) dan Tepung MOCAF (Modified Cassava Flour) Sebagai Substitusi Tepung Terigu Terhadap Karakteristik Fisik, Kimia, dan Sensori Cookies. Universitas Sebelas Maret

Wulandari, Tenri. Ghozali, Thomas. Taufik, Yusman. 2016. Optimalisasi Formulasi Minuman
Fungsional Black Mulberry (Morus nigra L) Dengan Design Expert Metode Mixture DOptimal Universitas Pasundan. Bandung. 